INTERNATIONAL JOURNAL OF RESEARCH IN SOCIAL SCIENCES \& HUMANITIES

An International Open-Access Peer Reviewed Referred Journal

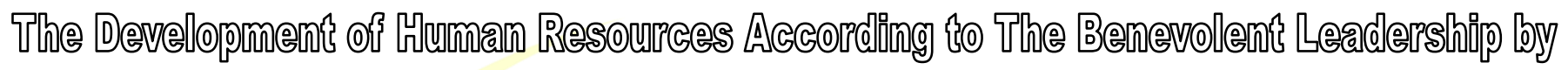

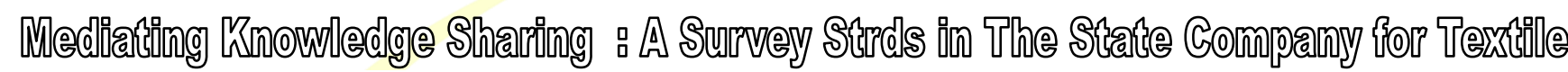

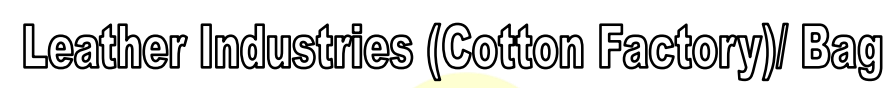

Ameer Abbas Rahmatullah, Atheer Abdullah Mohammed

University of Baghdad, College of Administration and Economics, Wasit, Iraq

DOI: http://doi.org/10.37648/ijrssh.v11i01.014

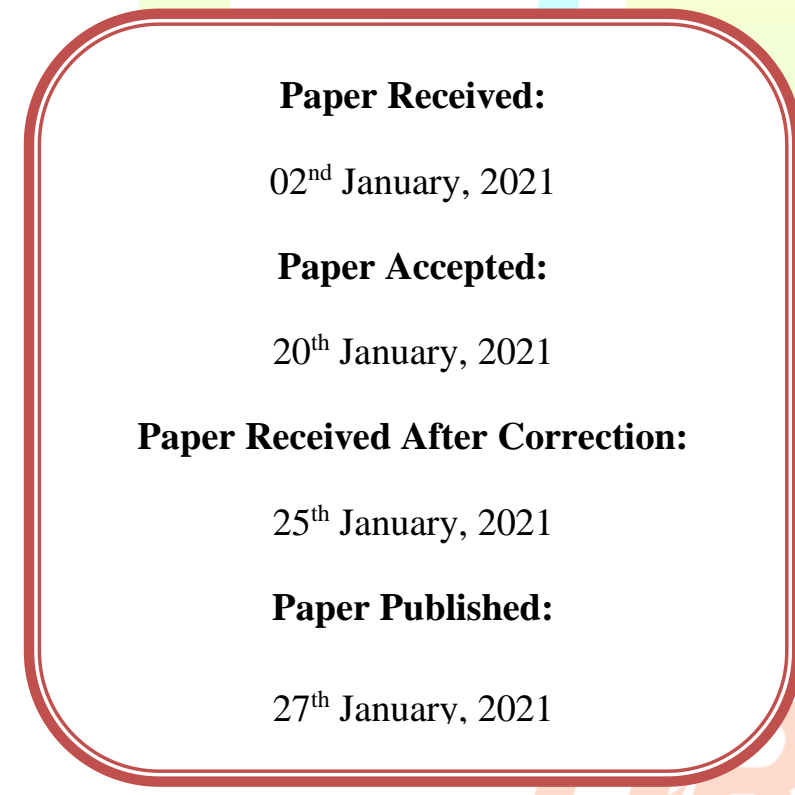

e-ISSN: 2249-4642; p-ISSN: 2454-4671

2021

International Journal of Research

in

\section{Social Science}

\&

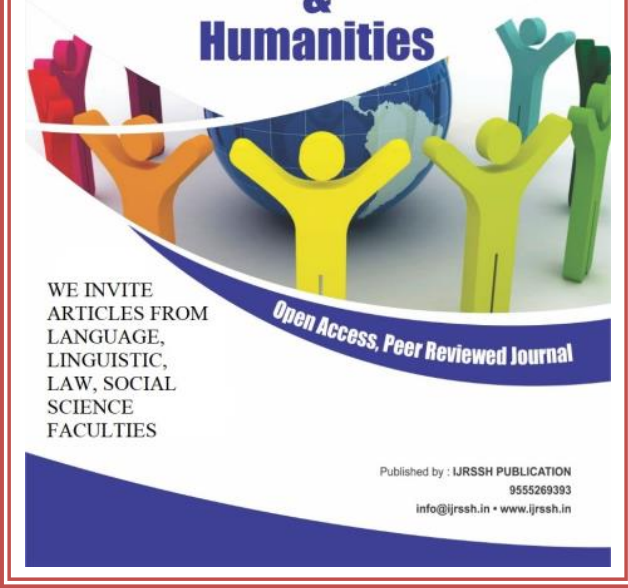

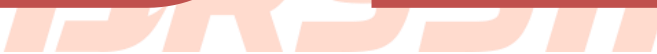

How to cite the article: Ameer Abbas Rahmatullah, Atheer Abdullah Mohammed, The Development of Human Resources According to The Benevolent Leadership by Mediating Knowledge Sharing : A Survey Strds in The State Company for Textile and Leather Industries (Cotton Factory)/ Bag, IJRSSH, January-March 2021 Vol 11, Issue 1; 231-251, DOI: http://doi.org/10.37648/ijrssh.v11i01.014 


\begin{abstract}
This study aims to clarify the role of human resource development as a dependent variable according to good leadership as a variable Independent knowledge-sharing mediator in the State Company for Textile and Leather Industries (Cotton Factory) Baghdad Textile Factory. The problem of the study is represented by the lack of interest in human resources by the factory administration and the weakness of the leadership role Good, which negatively led to the development of human resources. As well as identifying the levels and reaching a set of recommendations in order to contribute to improvement and increase Knowledge sharing in the researched organization. To achieve the goal in the researched organization, an exploratory and analytical approach was adopted in carrying out this study As the results shown in the current study highlighted the validity of the multiple compound linear model for an impact study The components of the benevolent leadership styles, and with a trace of the intermediate variables represented B (components of knowledge-sharing methods) on the human resource development function Where the significance of the common variations caused by the direct and indirect impact factors in the development index HR This reflects the importance of the combined analysis outputs in achieving the goals that the mission came about Research topic.
\end{abstract}

Keywords: benevolent leadership, human resource development, knowledge sharing 


\section{INTRODUCTION}

The industrial sector is witnessing, especially the cotton factory / The Baghdad Textile Factory has major challenges due to the instability of the political and economic conditions, the lack of protection for the national product and the lack of interest in the employees in the factory, which cast a delusion on the product, As the human element is considered one of the most important elements on which Baghdad Textile Factory depends in implementing its activities and programs and achieving its goals, The factory administration is still looking at how to make this important element present its best for the benefit of the lab in order to achieve its goals, And for these reasons, which called for the emergence of benevolent leadership in the laboratory in order to have a wide impact on the employees and the organization, Because it has a positive role towards employees, Knowledge Sharing plays a big role in this Knowledge is higher than the concept of information, while knowledge represents the optimal use of information Capabilities, experience and skills In order to understand and realize events, phenomena and facts in a clearer and wider way, since knowledge represents the source that It is characterized by the organizations and the main pillar for its success and development.

The Research Problem :The industrial sector suffers from a lack of interest, which has cast a perversion on the national product, whose role has become shy in entering the markets and competing with imported products due to the lack of protection for it and the lack of legislation to limit this, The Baghdad Textile Factory suffered from this shortcoming, in addition to the benevolent leadership role that did not receive the attention of the factory management, Therefore, the research problem arises by answering the following main question: Is there a role to develop human resources according to the benevolent leadership in mediating participation Cognitive? It is through this main question that a number of sub questions emerge, what is the reality of the perception of the people and unit managers in the Baghdad Fabric Factory of the concept of benevolent leadership (spiritual depth, positive participation, community response, moral sensitivity)? What is the extent of interest in developing human resources (training, career development, guidance) in the researched organization, What is the level of influence of benevolent leadership in developing human resources in the research organization? What is the level of Knowledge Sharing (the individual 
dimension, the organizational dimension, Technological dimension) By employees of the researched organization?

\section{The Importance of Research :The} importance of the study lies in the fact that it deals with one of the most important topics in the field of organizational behavior, which is the : benevolent leadership that has come into close contact with the essence of industrial organizations, especially since these industry organizations are working in an environment of development and renewal, which affects the development of human resources, as the importance of research is highlighted through its axes. The following: The importance of the study is highlighted by its focus on the industrial sector as it is one of the most important sectors at the level of the national economy through its focus on one of the most important industries, namely the textile industries, The current study will provide decision makers in the researched organization with a lot of discussion related to the study variables by diagnosing and showing strengths to enhance them and weaknesses to address them and diagnose the extent of Baghdad Textile Factory's vision of the role of benevolent leadership and its importance in developing human resources, as well as generating a process of Knowledge Sharing to be an important tributary in strengthening the relationship between benevolent leadership And the development of human resources and then achieve the goals that the organization seeks to achieve in order to raise the standards And staff capabilities. The importance of the study stems from the importance of the variables and their dimensions in the laboratory to push the wheel of development and development in the laboratory and work to raise the level of performance efficiency they have.

The Objectives of The Research: The main objectives of the research are the following Building a theoretical model for benevolent leadership and its dimensions (spiritual depth, positive participation, societal response, and moral sensitivity) through the relevant literature to be used in the practical framework of the study. Diagnosis of the nature of the relationship between the components with regard to the form and content of developing human resources (training, career path development, guidance) to improve employee efficiency towards improving overall productivity. Identify the role of benevolent leadership in developing human resources in the research laboratory The lab, Study the reality of adopting Knowledge Sharing (the individual dimension, the organizational dimension, the technological dimension) And its requirements in the intended place in order 
to expand the scope of knowledge and reduce costs.

Benevolent Leadership: The concept of philanthropic leadership differs from other leadership concepts because of its central focus on creating perceived benefits, businesses, or results for the sake of "the public good. the society. The Environment and a Sustainable Future or 'Leadership for the Good: Tackling Public Problems in a World of Shared Power (Karakas \& Sarigollu, 2012: 6). As the benevolent leadership was proposed as one of the sectors within the framework of the patriarchal initiative and the patriarchal authority means that the pioneer will continue like a father with his followers will take care of the workers and help them in every conceivable place (Alatf \& Anjum, 2018: 2). benevolent leadership comes from within and it is one of the ways to become a conscious, benevolent leader in your life. You must also be willing to create a life greater than what you have now and make a difference in the world. If you want to be a good leader, you must commit to living a life that transcends the limitations of what the rest of the world thinks, just as you must desire to be everything, No matter anything you must be prepared. the rest of the world thinks, just as you must desire to be everything, No matter anything you must be prepared. Complete, therefore, and from this space a completely new world opens up to you (Bowman et al, 2015: 13). benevolent leadership can also be expressed as a form of individual care in the field of work, such as providing opportunities to correct mistakes, avoid public humiliation of subordinates, and provide training and direction. Seeking to solve subordinates' work problems, and showing interest in the subordinate development profession, It can also be expressed as a form of individual sponsorship within a field other than work, Such as treating subordinates as members of the family.And assisting subordinates during personal emergencies .Demonstrating a comprehensive concern beyond professional relationships (Erkutlu, 2018: 109).In addition, benevolent leaders convey their role expectations to their followers and tend to use affectionate and affectionate actions to inspire subordinates a sense of responsibility and loyalty to their expected roles. Additionally, benevolent leaders can instill confidence in their followers (Shaw et al, 2020: 5).

\section{Human Resource Development: Human} resource development activities begin when an employee joins an organization and continue throughout his career regardless of whether this employee is an executive or an employee on the assembly line (Werner \& DeSimone , 2011: 4). The idea of developing human resources is to 


\section{Volume: 11, Issue: 1, January-March 2021}

develop and use human skills and knowledge through development. The organization and employee training in particular to achieve the goal through improvement and increase in organizational performance ( Saengchai et al, 2020: 3476).The primary purpose of developing human resources is to contribute to the longterm strategic performance and immediate improvement of performance, By ensuring that the members of the organization reach the desired goal after developing their capabilities to perform and meeting the strategic needs of the organization and the requirements of their jobs (Werner,2014: 133).

Knowledge Sharing : Knowledge sharing assists employees to share implicit and explicit knowledge as well as generate new knowledge among employees It promises to share, share and collect knowledge in order to foster innovation and creativity that ultimately leads To achieve goals and gains while gaining outstanding organizational performance (Obaid, 2020: 51) It includes a number of aspects, including activities aimed at exchanging knowledge and experience between researchers and between Policy makers, service providers and stakeholders To reinforce practices and decision-making Evidence-based The other activity is the situation in which knowledge is shared and is not clearly meaningful (Al-Yasiri, 2015:

31) Participation consists of a set of common understandings related to providing employees with access to Relevant information, building and using knowledge networks within organizations for achieving Goals (Areekkuzhiyil, 2019: 2).

\section{The Relationship Between Benevolent}

\section{Leadership And Human Resource}

Development : Best leaders show an interest in the career development of subordinates and try to understand the reasons behind performance They provide training and guidance and give opportunities to correct mistakes at work Goodness treats employee leaders as family members (Lin et al, 2018: 3) As organizations adopt various strategies to enhance creativity and innovative behavior for competitive advantage And survival, which is especially important for those who rely on large projects that require teams To appreciate and benefit from distinct knowledge within and across teams, and to achieve this innovation is needed Good leadership to enhance the innovative capabilities of teams by coordinating their collective experiences and actions if not Good leaders not only directly motivate their subordinates but also reinforce the family feeling among them And increase their identification of each of their teams and departments, 


\section{Volume: 11, Issue: 1, January-March 2021}

which in turn facilitates cooperation inside and outside the teams (Gumusluoglu et al, 2017: 479) It encourages employee behaviors to set development goals and engage in development activities and give More attention to the impact of their progress As employees must be more flexible in the face of failures, which facilitates them to initiate solutions and develop Self at the same time benevolent leadership nurtures the environment for open communication, mutual participation and inquiry Being active, which encourages employees to actively seek feedback and make improvements Facilitate their own development (Zhou et al, 2020: 4) People are naturally the essence of management and serving the government and organizations in recent years As the search for the innovative behavior of employees in the field of knowledge in the theoretical community is becoming increasingly common That leadership ability has played an important role in the success of the organization is especially important for the organization to be The employee is directly subordinate to the leader The relationship between leaders and employees is very important, and the relationship between employees and leaders has an impact Directly on the performance of the employees, especially if the relationship between them was good, the performance of the employees was better either The poor relationship between leaders and employees leads to worsening employee behavior

$(\mathrm{Wu}$, 2018: 479). benevolent leadership targets the subordinate after the leader discovers unethical behavior of subordinates before Other colleagues It is easy for negativity to bring about the consequences for themselves, including negatively affecting them Their career development, as subordinates need stronger positive incentives for career commitment with their leaders universe Good leaders care about the employees and their needs, while generating trust and security among the employees reflected positively on Developing their career potential and their creativity and skill at work, as well as that they may be on Willing to take any action on behalf of the organization to serve it, and benevolent leadership that draws interest The needs of subordinates will motivate them to pay attention to and achieve the goals of the organization (Shaw \& Liao,2020: 3). A good relationship between a good leader and an employee may excite the employees To feel the support of leaders in every aspect of life, so the effectiveness of philanthropic leadership in developing strength A productive worker has been highly demonstrated in organizations that follow a benevolent leadership style though The tremendous transformation 


\section{Volume: 11, Issue: 1, January-March 2021}

that industries are witnessing in modern development, which is in harmony with the development of employees in order Increase efficiency and improve productivity to achieve the goals of the organization (Tan, 2015: 323).

\section{The Relationship Between Benevolent}

\section{Leadership And Knowledge Sharing}

Leadership: in the twenty-first century faces many challenges, so it must be effective in the knowledge environment Global leadership, as the leadership must take a role more than ever before in providing assistance to the organization in order Confronting challenges as a result of the expansion of the scope of knowledge, including the challenge of knowledge sharing, and the leadership role is focused To promote and inculcate the values of knowledge sharing for employees working in the organization through clarification The purpose of knowledge sharing, as well as providing sufficient time for employees to interact with each other Development of reward policy and information technology systems (Al-Shehri, 2017: 27). She points Leadership refers to the relationship between the leader and his subordinates as the leadership develops and organizes the organization's own resources for Achievement of goals As well as communicating and exchanging experiences and knowledge however the organization tries in a way Innovative smart is that you compete for leaders' abilities to pool new and valuable ideas to become Skills are basic and renewable (Marjah, 2019: 104). That show Care and concern for employee welfare through benevolent leadership and creating a family environment conducive to effective management Personnel in the area of knowledge, as family relationships in new product development teams increased through Knowledge sharing inside and outside of teams due to good leaders' focus on facilitating special behaviors Team reciprocity in research and development settings, as innovative behavior across the team involves an exchange Knowledge, resources, collaboration and coordination with other teams to implement solutions to problems as well as guide ideas Developed by the team in innovations and implementation of new practices across the organization to achieve Objectives (Gumusluoglu et al, 2017: 481). A benevolent leader can create a vision for an employee And directing people to have a common vision of working for the organization and approaching goals Pointed out position Professional staff regarding knowledge as private property and not sharing knowledge and experience with supervisors Others hold the position of information ownership as having power under traditional hierarchical organizations 


\section{Volume: 11, Issue: 1, January-March 2021}

That would offer selfishness to the transparency of information That is why the executives need to be in the organization Private management practice tactics to stimulate knowledge exchange and participation in the organization to shape the organization's culture Helpful (Tang, 2017: 5428). Good leaders also tend to share knowledge and opinions more or less More inclusive and constructive with subordinates if they establish quality relationships with them These are considered valuable resources The knowledge-sharing processes will provide the subordinates with important information and knowledge that helps them Developing higher levels of creativity, leaders and followers As benevolent leadership promotes subordinates' gratitude towards Leaders, trust them and identify with them They feel obligated to share knowledge in more work Creativity and having more valuable information and knowledge resulting in better creative production for the organization (Lin et al, 2018: 4).

\section{The Relationship Between Human} Resource Development And Knowledge

Sharing: That successful knowledge sharing involves expanding learning processes rather than simple communication processes, Such ideas on development and innovation must be locally applicable with the adaptation you make Existing organizations (Cummings, 2003: 2) As human competencies have become an important source of construction for competitive advantage, which is difficult to imitate The competitors side because of the strategic role it can play in behind the added value Through its ability to innovate, the skill to achieve outstanding performance As the dynamics related to the management and development of human competencies require the establishment of an interactive, reciprocal relationship Group learning between individual competencies through collaboration and synergy in order to move to the level of competencies Collectivism and this can only happen through adopting the method of sharing knowledge and applying it on the ground Which is considered an essential pillar in creating the appropriate environment for work, which encourages communication as well as cooperation The teamwork, which in turn leads to the exchange of knowledge and the dissemination of good practices with successful competencies Collective response to confront the circumstances surrounding the work (Obaidat\& Jajeeq, 2014: 128,127) The development of human resources has traditionally been about enhancing personal experience through training They are usually weakly related to core competencies or knowledge 


\section{Volume: 11, Issue: 1, January-March 2021}

base As the core competencies of the organization must be identified through strategic planning for senior management and taking into account Current knowledge base There are several factors that help the success of the organization through the information on the knowledge base which is not established Assuming that characterizes the status of the organization and influences the content, form and success of development of employee efforts Among them (Ritva \& Riitta, 2007: $44,45)$.

1) The nature of the organization 2) Directs its strategic business 3) Current development strategy 4) Development ownership 5) Institutional culture and values 6) People's requirements and capabilities. Organizations seek to make great efforts in order to pay attention to human resources by monitoring and evaluating performance For the knowledge that includes the strengths and weaknesses in the completion of the work of the employee within the organization The performance of human materials expresses the extent of achievement and accomplishment of the task through observations and experiences as a process Group interaction allows the transfer of knowledge from one person to another within the organization through contact (Burgundy and Dries, 2015: 849) The world is more competitive and unstable than ever before Because of dependence on manufacturing As industries seek to gain a competitive advantage at any cost and are moving towards More innovation through human resource management practices that were specific in several aspects As a system that attracts, develops, motivates and retains employees to ensure effective implementation and survival of the organization And its members and achieve its goals They are practices that the organization uses to develop competencies and are productive for relationship Social complex and generating organizational knowledge that employees need for the purpose of knowledge sharing among themselves In order to maintain a competitive advantage (Tan \& Nasurdin, 2011: 157) It develops employees Cognitive commitment to the extent that they see the cognitive value And the development of competence in the use of knowledge And to maintain a working relationship or interaction with knowledge And be prepared to put in the extra effort to work With knowledge That the organization needs to adopt the perspective of active learning through which it reinforces the attitudes that are made Where knowledge is exchanged The most important factors for any knowledgesharing process are those that support or It gives the recipient the ability to assimilate knowledge (Cummings, 2003: 9) Learn the 


\section{Volume: 11, Issue: 1, January-March 2021}

employee from Failure and selfdevelopment reflect self-development to the extent to which the employee plans to participate in the tasks Gain information and knowledge about how to maintain and improve performance in the long term Self-development is self-motivated and future-oriented It enhances one's knowledge and stimulates a positive attitude For improvement and deep thinking produces more extensive and useful information within the organization (Zhou et al, 2020: 3). The innovative organizations will facilitate an understanding of the enabling method and the critical success factors for innovation and management Knowledge and learning is carried out for competitive advantage A learning culture prepares the leader for proactive change and benefits Knowledge exchange is from developments in any part of an educational organization working to improve knowledge flow Play Human resource development has a pivotal role in driving innovative activities using responsive guidance Within the organizational levels (Beyerlein et al, 2017: 26). Therefore, it is not possible to develop employees, not even the organization, without applying knowledge to reality and sharing it between Employees and transferring them fruitfully in order to achieve the goals of the organization, Figure (8) illustrates the role of cognitive sharing in influencing employee development and their competencies.

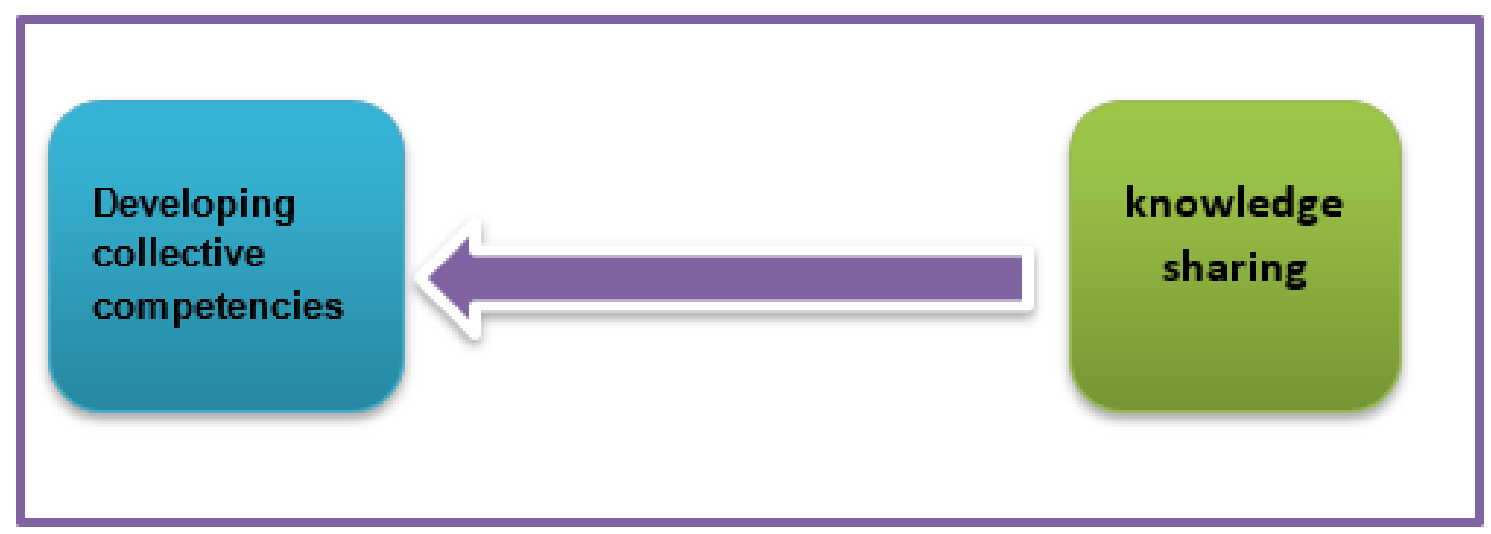

Figure (8) Model of the relationship between knowledge sharing and human resource development 


\section{The Hypothetical Outline of The}

Research: In order to reach answers about the questions of the study problem and achieve its objectives, a hypothetical translation scheme was designed The research problem refers to the practical framework in order to analyze and interpret the results, as Figure 1 shows the existence of Three main variables are represented by the first independent variable (charitable leadership) and the second dependent variable (development Human Resources) and the third intermediate variable (knowledge sharing) And the model movement is there A direct influence relationship between the three research variables (charitable leadership, human resource development, and participation Cognitive) This is shown by the hypothetical model of the research.

\section{As can be seen from figure (1), there are} four main hypotheses as the follows:

- H1 : There is no effect of the benevolent leadership styles on the overall development human resources and the dimensions in the researched organization, at a signifient level greater than 0.05 .

- H2 : There is no impact of knowledge sharing methods on the development of human resources as a whole and at the level Dimensions in the searched organization, at a significance level greater than 0.05).

- H3 : There is no effect of benevolent leadership styles on cognitive sharing methods as a whole and at a level Dimensions in the searched organization, at a significance level greater than 0.05 .

- H4 : There is no effect of benevolent leadership styles represented by (spiritual depth, positive participation, and response) Societal, moral sensitivity) on the development of human resources, with the presence of an effect of the representative variable By methods of knowledge sharing represented by (the individual dimension, the organizational dimension, and the technological dimension) at significance level greater than 0.05 . 


\section{Volume: 11, Issue: 1, January-March 2021}

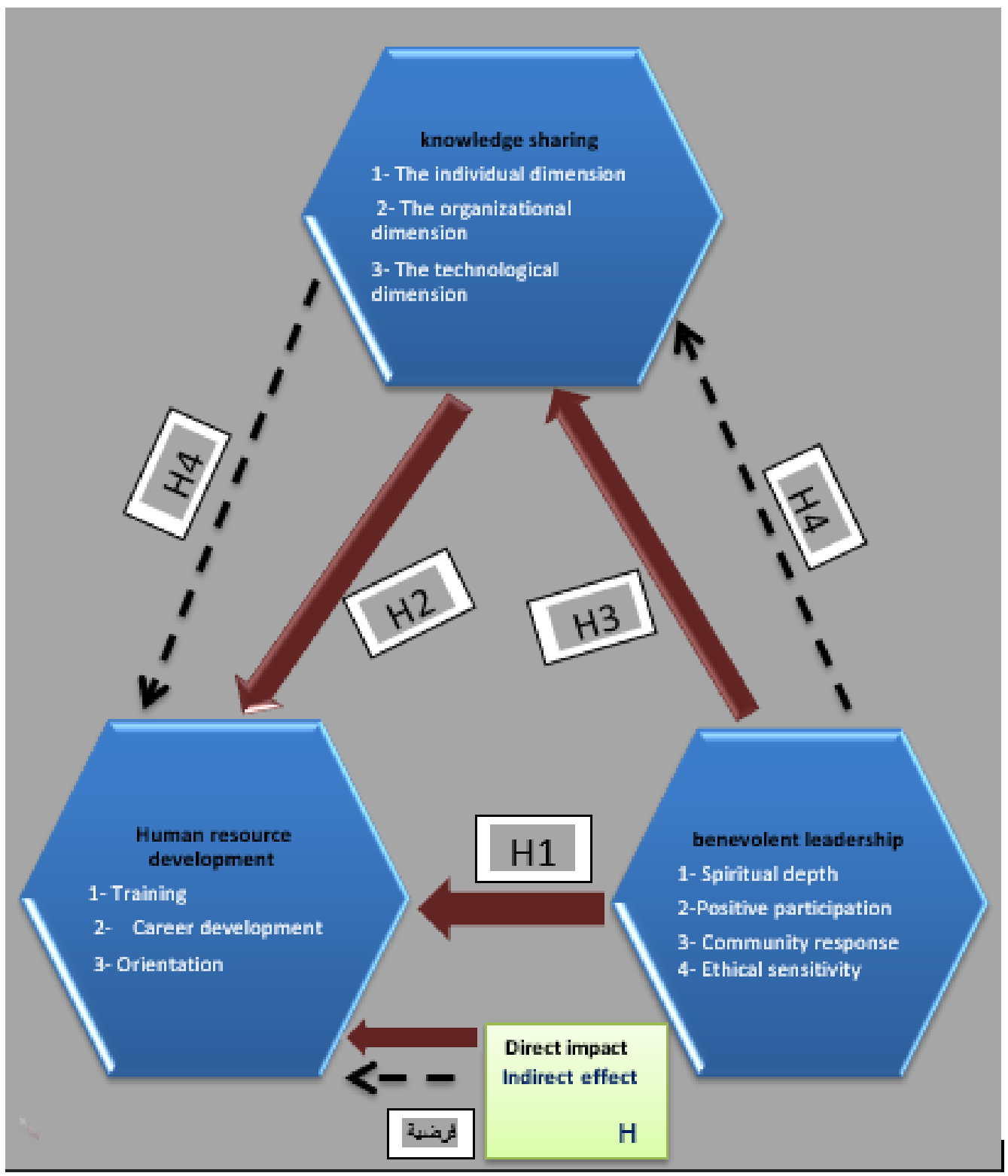

Figure. (1) the hypothetical model of the research

Source: prepared by the researcher

Practical side :The relationship of the lower subdomains to each other Table No. (1) displays the simple correlation coefficients for (Pearson) between the total averages of the measurement (Grand Mean of Score) for axes on the five-graded Likert scale which are shown Clearly, the degree of strength of the relationship between the aforementioned axes in general and in significant terms of less than one level Adopted significance 0.05, With the exception of some correlations whose significance levels indicated insignificance It is not significant, with a significance greater than the 0.05 level. 
Table (1): Estimating the correlation coefficients between the sub-axes of human resource development and axes Philanthropic leadership styles and cognitive sharing under the Pearson Simple Correlation Index

\begin{tabular}{|c|c|c|c|c|c|c|c|c|c|c|c|}
\hline التكنولوج & المنظمي & الفردي & الموارد & التوجيه & الوظيفير & التدريب| & الاخلاقية & الاستجابة & الايجابية & & $\begin{array}{l}\text { Correlation } \\
\text { Matrix }\end{array}$ \\
\hline 0.198 & 0.171 & 0.205 & 0.126 & 0.082 & 0.083 & 0.143 & 0.088 & 0.188 & 0.449 & Spiritual depth & \multirow{14}{*}{$\begin{array}{l}\text { Correlation } \\
\text { Sig. (1-tailed) }\end{array}$} \\
\hline 0.024 & 0.045 & 0.020 & 0.105 & & 0.207 & 0.079 & 0.191 & 0.030 & 0.000 & Sig & \\
\hline 0.046 & 0.015 & 0.197 & 0.187 & 0.154 & 0.115 & 0.186 & 0.267 & 0.407 & & Positive & \\
\hline 0.326 & 0.443 & 0.025 & 0.032 & 0.063 & 0.127 & 0.032 & 0.004 & 0.00 & & participation & \\
\hline & & & & & & & & & & Sig & \\
\hline 0.115 & -0.062 & 0.186 & 0.147 & 0.011 & 0.066 & 0.278 & 0.516 & & & Community & \\
\hline 0.127 & 0.271 & 0.032 & 0.072 & 0.456 & 0.257 & 0.003 & 0.000 & & & responseSig & \\
\hline 0.181 & 0.022 & 0.189 & 0.199 & 0.068 & 0.082 & 0.333 & & & & Moral sensitivity & \\
\hline 0.036 & 0.414 & 0.030 & 0.024 & 0.250 & 0209 & 0.000 & & & & Sig & \\
\hline 0.478 & 0.350 & 0.403 & 0.790 & 0.371 & 0.541 & & & & & Training & \\
\hline 0.000 & 0.000 & 0.000 & 0.000 & 0.000 & 0.000 & & & & & Sig & \\
\hline 0.458 & 0.496 & 0.453 & 0.860 & 0.525 & & & & & & Career & \\
\hline 0.000 & 0.000 & 0.000 & 0.000 & 0.000 & & & & & & development & \\
\hline & & & & & & & & & & Sig & \\
\hline
\end{tabular}


Volume: 11, Issue: 1, January-March 2021

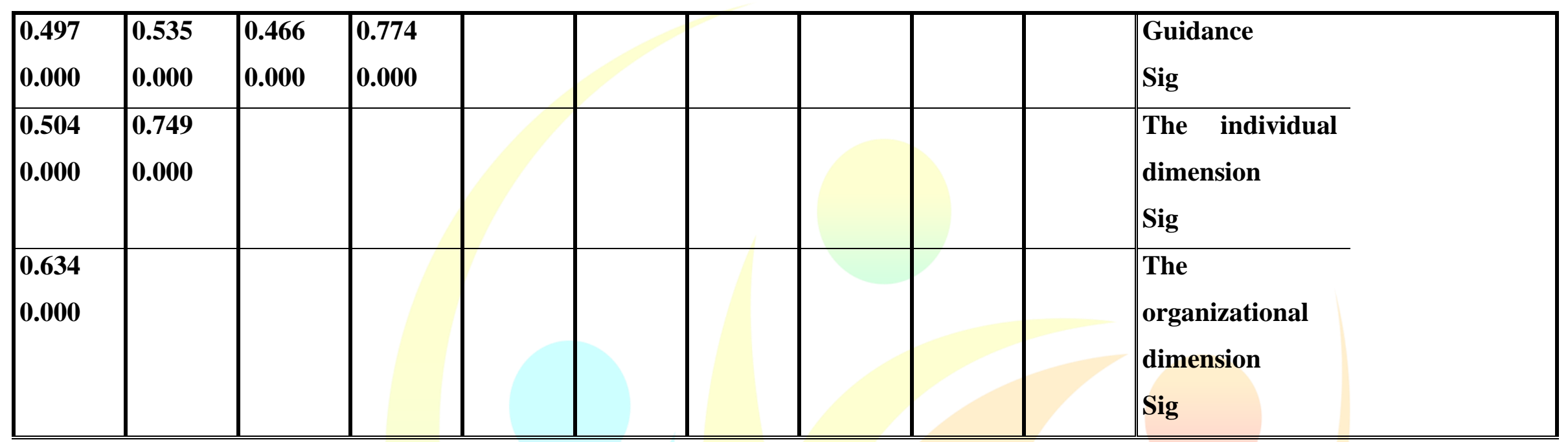

HS: highly significant with significance less than 0.01 ; S: significant in terms of less than 0.05 , NS: nonsignificant with significance greater than 0.05 . 


\section{Volume: 11, Issue: 1, January-March 2021}

Dimensions of human resources development according to the Benevolent leadership by mediating knowledge sharing: Table No. (2) displays the statistical summary of the results of the respondents on all aspects of resource development Humanity according to the benevolent leadership by mediating cognitive sharing, as it is evident that the general responses of the research sample are In light of the scale dimensions, it has achieved a high level among the general dimensions of the leadership, with a percentage of $4(100 \%)$, in When the results of the evaluation of the dimensions of the two axes of developing human resources and knowledge sharing were recorded at an intermediate level They converge to a high degree of high standard, at $3(100 \%)$ each.

Table (5): Descriptive statistics of the results of the respondents on all axes The development of human resources according to the charitable leadership by mediating knowledge sharing.

\begin{tabular}{|c|c|c|c|c|c|}
\hline $\begin{array}{l}\text { Rating } \\
\text { score }\end{array}$ & $\begin{array}{l}\text { GRS } \\
\%\end{array}$ & PSD & GMS & No. & Dimensions and sub-axes \\
\hline $\bar{H}$ & 75.43 & 0.60 & 3.77 & 100 & Spiritual depth \\
\hline $\mathbf{H}$ & 80.60 & 0.65 & 4.03 & 100 & Positive participation \\
\hline $\mathbf{H}$ & 75.97 & 0.63 & 3.80 & 100 & Community response \\
\hline $\mathbf{H}$ & 79.33 & 0.72 & 3.97 & 100 & Moral sensitivity \\
\hline $\mathbf{H}$ & 77.83 & 0.46 & 3.89 & 100 & Leadership Benevolent \\
\hline $\bar{M}$ & 70.64 & 0.86 & 3.53 & 100 & Training \\
\hline $\mathbf{M}$ & 67.24 & 0.90 & 3.36 & 100 & Career development \\
\hline $\mathbf{M}$ & 70.76 & 0.83 & 3.54 & 100 & Guidance \\
\hline $\mathbf{M}$ & 69.55 & 0.70 & 3.48 & 100 & Human resource development \\
\hline $\mathbf{M}$ & 70.52 & 0.82 & 3.53 & 100 & The individual dimension \\
\hline $\mathbf{M}$ & 71.56 & 0.89 & 3.58 & 100 & The organizational dimension \\
\hline $\mathbf{M}$ & 69.96 & 0.78 & 3.50 & 100 & The technological dimension \\
\hline $\mathbf{M}$ & 70.68 & 0.72 & 3.53 & 100 & Knowledge Sharing \\
\hline $\mathbf{M}$ & 72.68 & 0.49 & 3.634 & 100 & All dimensions are in compact format \\
\hline
\end{tabular}

Score for letter $(\mathrm{H})$ Means the rating is high, the letter $(\mathrm{M})$ It means that the rating is average 


\section{Volume: 11, Issue: 1, January-March 2021}

Where the results of all three axes recorded an average plane converging with a very high degree of level high, Where the relative importance of the( Global Mean of Score- GMS ) is in the formula Compact indicates, beyond any doubt, the high level of evaluation, with a general relative sufficiency of $(72.68 \%)$ And a common standard deviation of (0.49) on a single scale degree. In light of the foregoing, The high degree of insights toward the level of agreement is evidenced by the general population of sample respondents Research on the importance of what was included in the questionnaire of objective indicators, which paves the way for the implementation of steps
Extrapolation of the results of the inferences that will be based on the study and analysis of the effects resulting from the components of the charitable leadership And directly on the development of human resources and through indicating the indirect effects on the development process These resources are in order to investigate the validity of the assumptions of the model that depends on the results of quantitative measurements (variables (Related) to the conversion according to the overall measurement averages, tabl. (4) Shows the results of the test results of the fitment quality of the composite linear model for analysis of variance.

Table (4): Test of variance analysis of the compound regression of the function (human resource development) with a direct effect The components of the (Benevolent Leadership) index and the indirect impact of the components of Knowledge Sharing methods.

\begin{tabular}{|l|l|l|l|l|l||l|}
\hline $\begin{array}{l}\text { Indication } \\
\text { level }\end{array}$ & $\begin{array}{l}\text { F- } \\
\text { statistic }\end{array}$ & $\begin{array}{l}\text { Average of } \\
\text { squares }\end{array}$ & $\begin{array}{l}\text { Degree of } \\
\text { freedom }\end{array}$ & $\begin{array}{l}\text { Sum of the } \\
\text { squares }\end{array}$ & $\begin{array}{l}\text { Contrast } \\
\text { sources }\end{array}$ \\
\hline \hline \multirow{2}{*}{$\begin{array}{l}\text { HS } \\
\text { HS }\end{array}$} & \multirow{2}{*}{11.391} & 3.227 & 7 & 22.586 & Regression \\
\cline { 3 - 6 } & & 0.283 & 92 & 26.060 & Residuals \\
\cline { 2 - 6 } & - & 99 & 48.646 & Macro \\
\hline
\end{tabular}

HS: highly significant, with a significance of $<0.01$

Where it becomes clear and beyond doubt the validity of the multiple linear complex model to study the effect of method components Benevolent leadership, And with the presence of an effect of intermediate variables represented by (components of Knowledge Sharing methods) on a development function. $\mathrm{Hr}$ Where the significance of the common disparities resulting from the direct and indirect impact factors in the Human Resources 
Development Index, This reflects the importance of the combined analysis outputs in achieving the goals that the mission came about Research topic.

\section{CONCLUSIONS AND DISCUSSION OF RESULTS:}

1- The majority of the sample responses for the study in light of the scale dimensions achieved a high level among the general population Dimensions of good leadership, by\%, Whereas, the results of the evaluation of the dimensions of the two axes of developing human resources and knowledge sharing were at an average level It converges to a high degree of high standard and in proportion.

2- Exploiting knowledge sharing increases levels of efficiency and effectiveness Organization management.

3- Knowledge sharing offers many opportunities for managing an organization to find solutions Of the problems you face through the accumulation of knowledge that emanates from them.
4- The validity of the complex multiple linear model to study the effect of the components of the last leadership styles, And with the presence of a trace of intermediate variables represented by (components of cognitive sharing methods) On the human resource development function, as the significance of the common variations resulting from direct impact factors And indirect in the human resources development index, which reflects the importance of the analysis outputs Composite in achieving the goals that came by the message in question.

5- There is high agreement among the sample members about the importance of developing human resources, which is represented in employee training Career development as well as mentoring, It is concerned with the employees within the organization as well as achieving its goals. 


\section{REFERENCES}

1- Al-Quraishi, Ihssan Kazem Sharif, (2007), Instructional and Nonparametric Methods in Statistical Tests, First Edition, Iraq, Baghdad, Al-Diwani Press.

2- Karakas, F., Sarigollu, E, (2012). Benevolent leadership: Conceptualization and construct development. Journal of Business Ethics, 108(4),pp. 537-553

3- BOWMAN, CHUTISA, DOUGLAS, GARY \& BOWMAN, STEVEN ,(2015), BENEVOLENT LEADERSHIP FOR A BETTER WORLD, COPYRIGHTC BY CHUTISA BOWMAN GARY DOUGLAS ,USA, Life Mastery (Aust) Pty Ltd.

4- Alatf, A., \& Anjum, H. (2018). Benevolent Leadership, Perceived Supervisor Support And Subordinate Performance. Journal of Management and Human Resource (JMHR), 1, 1-17

5- ERKUTLU, H. V(2018). Benevolent Leadership and Interpersonal Deviant Behaviors in Higher Education Yükseköğretimde Yardımsever Liderlik ve Kişilerarası Sapkın Davranışlar

6- Shaw, K. H., Tang, N., \& Liao, H. Y. (2020). Authoritarian-Benevolent Leadership, Moral Disengagement, and Follower Unethical Pro-organizational Behavior: An Investigation of the Effects of Ambidextrous Leadership. Frontiers in Psychology, 11, 590

7- Tan, J. X. (2015). The effects of benevolent leadership in ameliorating turnover problem in hotel industry. Review of Integrative Business and Economics Research, 4(4), $322-336$

8- Werner, J. M., \& DeSimone, R. L. R. L. (2011). Human resource development. Cengage Learning, Sixth Edition, Cengage Learning, South-Western 5191 Natorp Boulevard Mason, $\mathrm{OH} 45040$ USA.

9- Werner, J. M. (2014). Human resource development $\neq \neq$ human resource management: So what is it?. Human Resource Development Quarterly, 25(2), 127-139Al-Daini, Rashad Waheed Khudair, (2010), The Impact of Electronic Management and the Role of Human Resources Development In improving the organization's performance, an applied study from the viewpoint of the employees of the Rafidain Bank, a message Master of Business Administration / College of Business / Middle East University.

10-Al-Maghribi, Muhammad Al-Fateh Mahmoud Bashir, (2016), Human Resources Management, First edition, Jordan, Amman, Al-Jinan Publishing and Distribution. M 109 


\section{Volume: 11, Issue: 1, January-March 2021}

11-Ritva, L. M., \& Riitta, V. (2007). Competence management and human resource development. A theoretical framework for understanding the practices of modern Finnish organizations. Edita Helsinki

12-Lin, W., Ma, J., Zhang, Q., Li, J. C., \& Jiang, F. (2018). How is benevolent leadership linked to employee creativity? The mediating role of leader-member exchange and the moderating role of power distance orientation. Journal of Business Ethics, 152(4), 1099-1115

13- Gumusluoglu, L., Karakitapoğlu-Aygün, Z., \& Scandura, T. A. (2017). A multilevel examination of benevolent leadership and innovative behavior in R\&D contexts: A social identity approach. Journal of Leadership \& Organizational Studies, 24(4), 479493

14-Zhou, Q., Mao, J. Y., \& Tang, F. (2020). Don't Be Afraid to Fail Because You Can Learn From It! How Intrinsic Motivation Leads to Enhanced Self-Development and Benevolent Leadership as a Boundary Condition. Frontiers in Psychology, 11.

15-Saengchai, S., Joemsittiprasert, W., \& Jermsittiparsert, K. (2020). Human Resource Development and Success of Engineering Procurement Construction Project: What Role Engineering Education and Human Resource Competency Can Play. Test Engineering and Management, 82, 3476-3487.

16-Karakas, F., Sarigollu, E, (2012). Benevolent leadership: Conceptualization and construct development. Journal of Business Ethics, 108(4),pp. 537-553.

17-Obaid, Fatima Alaeddin, (2020), The role of strategic knowledge management practices in achieving performance Al-Mutamayez, Master degree in Industrial Management Science, College of Administration and Economics / University of Baghdad.

18- Al-Yasiri, Weam Wahhab Abdel-Hussein, (2015) The effect of cognitive Knowledge Sharing in the achievement of creativity Organizational Research, Analytical Research at Dhi Qar University, Master Thesis in Public Administration Sciences/College of Administration And Economics / University of Baghdad.

19-Areekkuzhiyil, S. (2019). Factors Determining the Knowledge Sharing Practices among Graduate Students in Kerala: An Empirical Analysis. Online Submission.

20- Wu, Y. (2018). The Influence of Paternalistic Leadership on the Creative Behavior of Knowledge Workers-Based on the Perspective of Psychological Contractual Perception. Open Journal of Business and Management, 6(2), 478-487. 


\section{Volume: 11, Issue: 1, January-March 2021}

21-Al-Shehri, Fawzia bint Zafer Ali, (2017), The role of academic leadership in developing knowledge sharing as well Members of the faculty at King Khalid University realize a master's thesis in educational administration and supervision , College of Education - King Khalid University.

22- Marjah, Zahraa Ghanem, (2019), The reflection of human resources flexibility in job performance by mediating Knowledge sharing, an analytical exploratory study in some Ministry of Housing and Municipalities companies, thesis $\mathrm{PhD}$ in Public Administration / College of Administration and Economics / University of Baghdad.

23-Tang, H. (2017). Effects of leadership behavior on knowledge management and organization innovation in medicine and health sciences. Eurasia Journal of Mathematics, Science and Technology Education, 13(8), 5425-5433.

24-Cummings, J. (2003). Knowledge sharing: A review of the literature, World Bank Washington, D.C.

25-Obaidat, Sarah, Jajeeq, Abdel Malek (2014),, the effect of knowledge sharing on developing competencies Collective, Practice Study in Meditram Algeria, Performance Journal of Algerian Enterprises, Issue (6), Pages (127-138).

26- Tan, C. L., \& Nasurdin, A. M. (2011). Human resource management practices and organizational innovation: assessing the mediating role of knowledge managementeffectiveness. Electronic journalof knowledge management, 9(2), 155.

27-Beyerlein, M., Collins, R., Jeong, S., Phillips, C., Sunalai, S., \& Xie, L. (2017). Knowledge sharing and human resource development in innovative organizations. Knowledge Management Strategies and Applications, 25-45. 